\title{
Die Belydenis in historiese verband
}

\section{AD Pont}

(Die eerste vyf artikels is lesings wat by die Kongres van die Kerkhistoriese Genootskap van die Ned Hervormde Kerk in Pretoria op 17 November 1981 gehou is.)

\section{INLEIDENDE OPMERKINGS}

In die kerk en in die kerklike lewe is daar voortdurend sprake van die belydenis. Die saak kom dan ook op verskillende vlakke en geleenthede pertinent in die lewe van die gemeente en die lidmaat na vore. Dit is ook verstaanbaar, want die belydenis van die geloof in God is so deel van die kerk en sy lewe dat die kerk, die volk van God; sonder belydenis ondenkbaar is. Die kerk is mos die volk van God wat bymekaar geroep is deur die enige Hoof en Heer van die kerk, Jesus Christus. Die belydenis is mos 'n antwoord van God se volk op die roepstem van sy Heer, op die aangespreek wees deur sy Heer, op die genadegawe van die geloof wat God gegee het ${ }^{1}$. In die kerk is die belydenis self noodsaaklik omdat daarmee die innerlike oortuiging uitgespreek word dat dit wat God openbaar, die waarheid is ${ }^{2}$. In die belydenis word uitgespreek wat God objektief in sy Woord openbaar en wat subjektief die geloofsbesit van die volk van God, die kerk is ${ }^{3}$.

Die belydenis kom dus in die kerk en in die lewe van die gelowige lidmaat reëlmatig na vore soos, byvoorbeeld, in die Sondagse godsdiensoefening waar die gemeente 'n geloofsbelydenis staande en instemmend aanhoor en nasê. Oor die belydenis stel die Kerkwet in art $\mathrm{XI}^{4}$ :

"1. In dankbare gehoorsaamheid aan die Woord van God wat deur die werking van die Heilige Gees bron en enigste inhoud van die prediking en reël van die geloof is, bely die Kerk in gemeenskap met die vadere, in besef van sy verantwoordelikheid vir die hede en in verwagting van die toekoms van die Here Jesus Christus, sy geloof in die Drie-enige God.

2. Die belydenis van die vadere word vervat in die Apostoliese Geloofsbelydenis, in die Geloofsbelydenis van Nicea en in die Geloofsbelydenis van Athanasius, die geestelike eiendom van die algemene Christelike kerk, sowel as in die Nederlandse Geloofsbelydenis, die Heidelbergse Kategismus en die Dordtse 
Leerreëls, wat deur die Hervorming aan die Kerk geskenk is.

3. Die Kerk bely in sy

(a) bediening van die Woord,

(b) bediening van die sakramente,

(c) gebede,

(d) belydenisskrifte,

(e) formuliere,

(f) kerklike liedere,

(g) leerboek,

(h) herderlike briewe, en

(i) getuienisse

telkens opnuut Christus as Hoof van die Kerk en as Heer van die wêreld.

4. Die Kerk weer uit sy midde alles wat die belydenis weerspreek."

Uit hierdie formulering blyk wel dat die belydenis van die geloof in God 'n vanselfsprekende deel van die lewe van die volk van God is, miskien meer nog ... dat dit die lewe van die kerk bepaal, want in die belydenis gaan dit om die geloof, die verbondenheid van die liggaam van Christus met sy Hoof.

' $n$ Besondere faset van die belydenis van die kerk is die samehang en verband van die belydenis met die Heilige Skrif. Omdat die kerk deur die prediking van die Woord gegrond, gebou en in gehoorsaamheid aan sy Heer gehou word, is dit van wesenlike betekenis dat die Woord van God reg verkondig sal word. Daarom moet elkeen wat tot die dienswerk van dienaar van die Woord toegelaat wil word, by sy toelating ' $n$ spesifieke onderneming gee en met sy handtekening bekragtig. Die onderneming en bekragtiging is die proponentsformule wat as volg lui ${ }^{5}$ :

"Ek, die ondergetekende, dienaar van die Woord van God in die Nederduitsch Hervormde Kerk van Afrika, verklaar hiermee dat ek die leer wat uitgedruk is in die formuliere van eenheid, naamlik die Nederlandse Geloofsbelydenis, die Heidelbergse Kategismus, en die Dordtse Leerreëls, en wat in ooreenstemming is met die Woord van God, van harte onderskryf en getrou sal verkondig...

Deur hierdie formule te onderteken, verklaar ek dat ek vas oortuig is en glo dat die leer wat in die formuliere van eenheid uitgedruk is, in volkome ooreenstemming met die Woord van God is."

Met hierdie ondertekening maak die voornemende predikant drie 
eerbiedwaardige belydenisskrifte wat uit die sestiende en begin van die sewentiende eeu stam, vir homself en vir die kwaliteit van sy dienswerk volkome ter sake en eietyds so lank hy predikant in en van die kerk is.

Uit hierdie aanduiding is dit duidelik dat die belydenis op verskillende vlakke van ons kerklike lewe gebruik word en funksioneer. Dit is nie toevallig dat dit so is nie, hoewel dit ook waar is dat daar in die kerk nie altyd by almal presiese duidelikheid is oor die rede waarom dit so is nie. Veral rondom die predikant se self-aanvaarde binding aan die belydenisskrifte is daar soms vraagtekens, veral by diegene wat die les van die geskiedenis van die kerk in die 18de en 19de eeu nog nie deurworstel het nie.

In die historiese oorsig wat hier gebied word, kan dit uit die aard van die saak, nie oor die geheel van die historiese agtergronde van die belydenis en sy funksie en plek in die kerklike lewe gaan nie. Hier sal dit in hoofsaak gaan oor die verhouding Skrif en belydenis soos dit in die proponentsformule na vore kom waar 'n geroepe gelowige belowe om 'n belangrike dienswerk in die kerk op 'n bepaalde manier te verrig, binne 'n bepaalde raamwerk sodat die geloof van die gemeente deur die verkondiging van die Woord gewek en gebou sal word. Dit moet duidelik gestel word dat as hier gehandel word oor die belydenis, gaan dit om die belydenis-vandie-kerk, van die gemeenskap van die gelowiges. Dit wil nié sê dat die belydenis die grondslag van die kerk is of selfs 'n konstitutiewe faktor in die "kerkverband" nie. Die grondslag van die kerk is "die Bybel as Woord van God" en verwys na Efesiërs 2:20 waar Paulus na die gemeenskap van die gelowiges verwys as "...'n gebou wat opgerig is op die fondament van die apostels en die profete, 'n gebou waarvan Christus Jesus self die hoeksteen is."

As ons so let op die belydenis, is dit duidelik dat dit menslike spreke is, menslike antwoord op die Woord van God. Dit wil egter nie sê dat die belydenis daarom op losse skroewe staan nie, want die kerk het die Gees van die waarheid (Joh 14:17) ontvang wat die kerk "in die hele waarheid lei" (Joh 16:13). Die belydenis in die kerk is die formulering van die waarheid soos die kerk dit uit die Woord van God hoor en verstaan. Hierdie waarheid word normaalweg in die kerk deur 'n meerdere vergadering van die ampte geformuleer en kan nooit die "privaat besit" van die enkeling-gelowige alleen wees nie.

Die verskillende aksente en funksies van die belydenis van die kerk waarmee al die gelowiges in die kerk saamstem as uitdrukking van hulle geloof, het geleidelik so in die kerk na vore gekom. Oor die historiese gang van sake kan die volgende opmerkings gemaak word. 


\section{IETS UIT DIE GESKIEDENIS VAN DIE VROEË KERK}

Reeds in die Skrif self kom die belydenis, die uitspreek van die geloof in Jesus Christus na vore ${ }^{6}$, ook vanweë die opdrag van Christus in Matteus 10:32: "Elkeen wat hom voor die mense openlik vir My uitspreek, vir hom sal Ek My ook openlik uitspreek voor My Vader wat in die hemel is." Juis daarom kom die belydenis as vanselfsprekend in die vroeë gemeentes voor. Dit wil egter voorkom asof ' $n$ belydenis wat méér sê as net die uitdrukking van die geloof in die Drie-enige God in die eerste eeu $(50-150)$ nog nie skriftelik in 'n spesifieke formule vasgelê is nie? ${ }^{7}$. Die formele belydenis wat as ' $n$ doopbelydenis, na kategese, deur nuwe bekeerlinge afgelê is, is in die eerste eeu nog voluit ' $n$ belydenis, dit wil sê 'n geloofsuitspraak en nie in die eerste plek ' $n$ omskrywing van die leer van die kerk nie. As sodanig is ' $n$ geloofsbelydenis ook in die godsdiensoefeninge gebruik. Ongeveer in die middel van die 2 de eeu word'n geloofsbelydenis in die gemeente van Rome en in die Klein-Asiatiese gemeentes gevind wat so in die godsdiensoefening gebruik wod. Dié geloofsbelydenis, wat op die verkondiging van die apostels teruggaan, druk die geloof in die Vader, die Seun en die Heilige Gees uit. Verder verwys dit na 'n paar belangrike momente in die lewe van Jesus Christus en bring dan ook die kerk, die vergiffenis van die sonde en die opstanding na vore. Dit is dus ' $n$ belydenis van geloof in die Drie-enige God en is daarvandaan toegespits op die heilsgoedere wat Christus nagelaat het ${ }^{8}$. Die basis vir hierdie geloofsbelydenisse is telkens die gesag van die apostels en hulle verkondiging?.

Met die opkoms van kettery in die kerk en veral as gnostiese invloede naas Judaïserende tendense na vore kom, ontstaan in die kerk die regula fidei. Dié regula fidei ontstaan uit die apostoliese tradisie d.w.s. die apostoliese geskrifte èn die mondelinge oorlewering. Dit geld dan as die essensie van die leer van Christus of ook van die leer van die apostels ${ }^{10}$.

Aanvanklik is daar geen algemeen aanvaarde regula fidei nie, maar elke Christelike skrywer formuleer self 'n regula waarmee hy die inhoud van die Christelike geloof, as fondament van die Christelike geloof, omskryf. So word die oorgelewerde waarheid nou bondig saamgevat as 'n regula fidei en dit word dan normatief vir die geloof van die Christen. Met die regula fidei as maatstaf word bepaal wat Christelik is en wat nie. So kry die bondige omskrywing van die geloofsinhoud die funksie van 'n geloofswet wat veral ten opsigte van die afwykende mening aangelê word ${ }^{11}$.

Die opkoms van die Gnostiek asook die verbreiding van die leer van Marcion maak dit noodsaaklik dat die oorgelewerde waarheid in die kerk duidelik omlyn moes word. Hiervoor is nie net ' $n$ belydenis nodig nie maar ook 'n uitleg van die basiese waarhede wat bely 
word. So word in Rome die belydenis as die fides catholica, as reël van die waarheid van die geloof vasgestel. Die aanvaarding van dié belydenis bepaal dan die lidmaatskap van die kerk. So het Irenaeus al in sy geskrifte die doopbelydenis, soos dit uitgelê is, as die apostoliese regula veritatis aangedui ${ }^{12}$. Die regula dui dan terselfdertyd die grense van die kerk as geloofsgemeenskap aan.

Teen die tyd wanneer die kerkvader Tertullianus (160-220) optree, is die begrip regula fidei al 'n omlynde begrip. Tertullianus stel dat die regula van Christus, d.w.s. van die apostels, afkomstig is en dat dit onvervals is en dat dit die geloof van die gemeentes wat deur die apostels gestig is, omskryf ${ }^{13}$. By Tertullianus is die regula fidei iets meer as net die omskrywing van die geloof. Hy sien dit as ' $n$ reël vir die geloof, as 'n wet of reël wat deur die geloof gegee is, selfs 'n regula doctrina $e^{14}$.

Tog is dit interessant om vas te stel dat ' $n$ tydgenoot van Tertullianus, Clemens Alexandrinus (150-215), die regula fidei nog nie as 'n omlynde belydenis sien nie. In sy Stromateis omskryf hy dit as die geheel van die Heilige Skrif oftewel die leer van die Here èn die normatiewe oorlewering ${ }^{15}$. Clemens gee dus 'n weergawe van die ouer standpunt, want Tertullianus stel dit al baie skerp dat die apostoliese lex et doctrina deur elke Christengelowige gehou moet word, want dit omskryf die grense van die kerk. Deur middel van die belydenis word die onderskeid tussen kerk en nie-kerk baie duidelik getrek ${ }^{16}$.

Voortdurend beklemtoon die kerkvaders egter dat die Heilige Skrif die volledige, selfstandige bron van die waarheid is wat as sodanig in waarde bo die belydenis staan. Die kerk het egter die regula fidei steeds onveranderd gehandhaaf en Tertullianus en Irenaeus gebruik die argument van die successio episcoporum om daarmee die onveranderlikheid van die apostoliese erfenis te beklemtoon. Immers die kerk is die geloofsgemeenskap wat voortdurend dieselfde geloof bely en dieselfde leer gehandhaaf het ${ }^{17}$.

Ongeveer teen die jaar 200 bestaan in die vroeë kerk die stelreël dat alles wat in die kerk wil bestaan aan die geloof, soos dit skriftuurlik vasgelê is in die doopbelydenis (die oervorm van die Twaalf Artikels), en aan die NT Skrifkanon getoets moet word. So word geleidelik die Twaalf Artikels die norm waarmee gemeet word. Tog word die doopbelydenis nog nie primêr as ' $n$ leer beskou nie. Die leer is die uitleg van die belydenis en vir die uitleg moet die Skrif gebruik word ${ }^{18}$.

Die Twaalf Artikels, soos dit in Rome ontstaan het, word dan die vaste kern waarvandaan die regula fidei geformuleer word. So ontstaan die vaste norm wat ook die grense van die kerk aandui, terwyl by Tertullianus ook al die gedagte voorkom dat die regula fidei op sy beurt ook weer die uitleg van die Skrif normeer" 
So kan gestel word dat na die vasstelling van die Twaalf Artikels in ongeveer die jaar 200 en nà die arbeid van Tertullians, Irenaeus en hulle tydgenote, die posisie van die belydenis as volg saamgevat kan word:

1. Dit is die uitdrukking van die geloof van die kerk;

2. dit is die onderskeidingsteken van die suiwerheid van die geloof teenoor die ketters en die afwykende menings;

3. dit is die middel om die suiwere geloof aan die nageslag oor te dra en om die ware geloof in die wêreld te propageer;

4. dit is aanduiding van die eenheid van die kerk met die waarheid en dit beklemtoon die eenheidsband van die kerk.

Hierin het daar feitlik geen verandering gekom as die vroeë kerk teenoor die ketters in sy midde die belydenisse op die verskillende ekumeniese konsilies in meer besonderhede uitlê nie. Opvallend is dan dat

(a) dit slegs 'n meerdere vergadering van die kerk (sinode of konsilie) ' $n$ belydenis kan formuleer of gesaghebbend ' $n$ leeruitspraak kan maak. Hiervandaan kry die belydenisskrif sy kerklike gesag;

(b) die belydenis altyd weer ' $n$ afgrensing teen die afwykende mening is sodat die belydenis dikwels slegs negatief stel hoe dit nié is nie, sonder om presies uit te spel hoe dit wèl is.

Dit is wel opvallend hoeveel geloofsbelydenisse deur sinodes en konsilies opgestel en aanvaar is. Tog het net drie geloofsbelydenisse uit die vroeë kerk as 't ware behoue gebly. Dit kan dan ook gestel word dat dieselfde reël wat geld ten opsigte van die dogmata van die kerk ook ten opsigte van die geloofsbelydenisse geld, nl. dat slegs dié geldigheid verkry wat oral, altyd en deur almal as in ooreenstemming met die Woord van God en as uitdrukking van die geloof van die kerk aanvaar is.

$\mathrm{Na}$ hierdie baie kursoriese inleiding word die situasie in die Middeleeuse, pouslike kerk links gelaat om nou aandag aan hierdie saak, soos dit in die Kerkhervorming na vore kom, te gee.

\section{TYDENS DIE KERKHERVORMING}

Die meeste Protestantse belydenisskrifte dateer uit die sestiende eeu en is in 'n sekere sin die resultaat van die teologiese debat, enersyds met die Roomse kerk en owerhede en andersyds met die Dopers, Antitrinitariërs en ander sektariese groepe en persone. Slegs 'n paar belydenisskrifte soos die Westminister Geloofsbelydenis van 1643 
en die ouer Dordtse Leerreëls van 1618-1619 ontstaan vanweë teologiese verskille binne die Protestantse kerk self.

Nieteenstaande die feit dat die Protestantse belydenisskrifte duidelike grense trek, is dit tog goed om te onthou dat die kerke van die Hervorming saam met die Roomse en Grieks-Ortodokse kerke die drie sg. ekumeniese simbole, nl. die Twaalf Artikels, die Geloofsbelydenis van Nicea-Konstantinopel en die genoem na Athanasius, gehandhaaf het.

In die kerke van die Hervorming het ' $n$ hele reeks belydenisskrifte na vore gekom. Op die voetspoor van $C$ Augustijn kan die plek en funksie van die belydenisskrifte binne die kerke van die Hervorming as volg geskematiseer word $^{20}$.

\subsection{Die belydenis as middel om die ware geloof aan die nageslag} oor te dra en in die wêreld te propageer

Hier gaan dit om die belydenisskrif wat primêr binne die kerk self gebruik word om so die eenheid in geloof en lewe te kry. Die kategismus is die mees tipiese van hierdie soort belydenisskrif. Die kerke van die Hervorming het dan ook ' $n$ hele reeks kategismusse opgelewer. Die eerste wat verskyn, is Luther se Groot en Klein Kategismus van 1529. Ander beroemde kategismusse is dié van Joh Calvyn van 1541 en die Heidelbergse Kategismus van $1563^{21}$. Hierdie kategismusse wat 'n uitleg van die essensiële van die evangelie is, is almal direk op die Skrif gegrond. Die Kategismus as belydenisskrif is primêr na binne gerig om die eenheid van die geloof en die eenheid met die waarheid in die kerk te formuleer. As sodanig is dit natuurlik ook uitdrukking van die geloof van die kerk.

\subsection{Die geloofsbelydenis as verdediging}

Die eerste voorbeeld van ' $n$ hervormde belydenis wat bedoel is om die bestaansreg van die Hervormde Kerk en leer aan te toon en te bewys dat die hervormde leer die Skrif volg op dié punte waar Rome van die Skrif afwyk, is seker die Geloofsbelydenis van Augsburg van $1530^{22}$.

Hier word die geloofsbelydenis nie primêr vir die eie kerklike kring bedoel nie, maar is dit die verdediging van die hervormde standpunt, soos gegrond op die Skrif, teenoor die keiser, die Ryksdag en die wêreld.

Hierdie aspek kom ook voor by die Franse Geloofsbelydenis van 1559 en die Nederlandse Geloofsbelydenis van 1561. By hierdie twee staan die apologetiese tendens egter minder sterk op die voorgrond as in die Augsburgse Geloofsbelydenis en sy Apologie. 


\subsection{Die geloofsbelydenis as aanduiding van die eenheid}

Dit is nogal merkwaardig om vas te stel hoe kort na mekaar die verskillende Calvinistiese kerke hulle geloofsbelydenisse opgestel het. So kom die Franse geloofsbelydenis in 1559 tot stand, die Nederlandse in 1561, die Skotse 'n jaar eerder in 1560 en die Hongaarse in 1563. Hoewel die inhoud van die geloofsbelydenisse grotendeels gelykluidend is, is daar tog ook weer duidelike verskille wat veroorsaak is deur die omstandighede waarin elke kerk verkeer ${ }^{23}$. Tog was daar een geloofsbelydenis wat veral deur die toedoen van Frederik III, die Keurvors van die Paltz, algemene instemming van al die Calvinistiese kerke gekry het. Dit was die Tweede Switserse Geloofsbelydenis van $1566^{24}$. Hierdie geloofsbelydenis het veral gedien om die geloofseenheid van die verskillende Calvinistiese kerke te onderstreep en terselfdertyd het dit ook die grense tussen die Calvinistiese kerke aan die een kant en die Roomse, Lutherse en ander kerke aan die ander kant getrek. Hierdie uitvoerige geloofsbelydenis wat sowel na binne as buite gerig is, het miskien meer as enige ander geloofsbelydenis die gemeenskaplike in die geloof van die Calvinistiese kerke onderstreep.

\subsection{Die geloofsbelydenis as onderskeidingsteken van die ware geloof}

Vir die doeleindes van ons gesprek is dit eintlik die faset van die geloofsbelydenis wat nou die belangrikste is. Dit word gou duidelik, as die geloofsbelydenisse bestudeer word, dat ook in die Calvinistiese kerke die geloofsbelydenis verstaan en hanteer word as die onderskeidingsteken van die ware geloof. Dit wil sê die geloofsbelydenis is aan die een kant die aanduiding van die geloofsgrense van die kerk en andersyds geld dit as 'n norm om in die kerk ten opsigte van die prediking, die geloof, die leer en die lewe van die lidmate en die ampsdraers te onderskei tussen reg en verkeerd, waar en niewaar-nie.

Dit is veral vanweë hierdie aspek en funksie van die belydenis dat die belydenis veral vanaf die $18 \mathrm{de}$ en $19 \mathrm{de}$ eeu herhaaldelik die onderwerp van soms heftige debatte was. Daarom is dit miskien belangrik om hier 'n bietjie meer in besonderhede in te gaan.

\subsubsection{Die posisie in die Lutherse kerke}

Luther self stel duidelik dat daar' $n$ regula fidei in die kerk is en moet wees wat as die norm vir waar en vals kan geld ${ }^{25}$, en wat terselfdertyd die geloofsgrense van die kerk aandui. Tog is die belydenisskrif nié vir Luther die saamgevatte regula fidei nie. Die regte verkondiging van die Woord is vir Luther die primêre en nie die verhande- 
ling van die inhoud van ' $n$ bepaalde geformuleerde belydenisskrif $n^{26}{ }^{26}$. Aanvanklik word dan ook nie aan die belydenisskrif 'n normerende rol toegeken nie, hoewel aanvaar is dat die belydenisskrif ' $n$ aanvaarde en geldige samevatting van die leer van die kerk is ${ }^{27}$. In die Formula Concordiae van 1577 wat in 1580 gepubliseer is en ' $n$ einde moes maak aan die interne twiste in die Lutherse kerke word aan die belydenisskrifte nie eksplisiet 'n normatiewe rol as regula fidei gegee nie, want daar word gestel ${ }^{28}$ :

"Maar die ander simbole en ander geskrifte, wat ons hier opgenoem het, het nie die gesag van 'n regter nie, want daardie eerbiedwaardige posisie (= dignitas) kom alleen aan die $\mathrm{H}$. Skrif toe. Hierdie simbole en ander geskrifte getuig slegs van ons geloof en sit dit uiteen om aan te toon hoe die Heilige Skrif van tyd tot tyd in die kerk van God deur doktore, wat toe geleef het, verstaan en uitgelê is ten opsigte van omstrede artikels en met watter argumente leerstellinge, wat in stryd met die Heilige Skrifte was, verwerp en veroordeel is."

Tog is dit interessant dat na die opsomming van die Lutherse belydenisskrifte en uiteensettings wat die leer van die kerk Skriftuurlik veranker, daar óók gestel word ${ }^{29}$ :

"Aan hierdie beginsels, soos hierbo uiteengesit, behoort elke godsdienstige leerstelling (= doctrina in religionis) te konformeer; en indien enigiets ontdek word wat daarmee in stryd is, dan moet dit verwerp en veroordeel word omdat dit nie ooreenkom met die eenstemmige uiteensetting van ons geloof nie."

Hoewel die Skrif as die enigste regula fidei gestel word, word tog ook weer gestel dat die regula fidei wat die Skrif gee, in die belydenisskrifte saamgevat en opgesom word. So word die belydenisskrif geleidelik op die voorgrond gebring as 'n normatiewe samevatting, as die regula fidei.

Dit is opvallend dat die Formula Concordiae nie 'n normatiewe, kerkregtelik omskrewe posisie in die Lutherse kerk gekry het nie. Dit hang weer saam met die feit dat Luther en sy opvolgers nie oog gehad het vir die Calvinistiese stelreël dat die kerklike orde as lewensreël van die kerk, normaalweg uit die geloofsbelydenis van die kerk voortkom en moet voortkom nie.

Die normatiewe rol van die belydenisskrif het in die Lutherse kerke langs ' $n$ ander weg tot stand gekom. Augustijn wys daarop dat in die jare 1558 en 1561, dus vóór die totstandkoming van die Formula Concordiae wanneer die Lutherse teoloë skerp verdeel is oor die Lutherse erfgoed, ' $n$ aantal Lutherse vorste bymekaargekom het om 
'n einde te probeer maak aan die teologiese twiste. In hulle pogings om dit te bereik, soek hulle aansluiting by die Augsburgse Geloofsbelydenis wat vanaf 1555 buitendien in die openbare lewe as die omskrywing van die Luthers-Hervormde leer in Duitsland gegeld het. In 'n uitvoerige verklaring stel die vorste dan dat die Heilige Skrif die primêre en onaantasbare kenbron vir die suiwere, ware leer is. Dan stel hulle egter verder dat die Augsburgse Geloofsbelydenis, as samevatting van die suiwere leer, aan die Heilige Skrif ontleen is en daarmee ooreenstem. Ten slotte verklaar die vorste dat hulle geen dwaalleer of sekte sal duld nie, maar sal bly vashou aan die korrekte en enigste maatstaf van die Goddelike, profetiese en apostoliese Skrifte en dus ook aan die Augsburgse Geloofsbelydenis en die Apologie wat op die Heilige Skrif gebou en gegrondves is ${ }^{30}$.

Hier, net soos effens later by die Formula Concordiae, word gestel dat die Heilige Skrif as die regula fidei geld. Maar dit het uit die Rooms-Lutherse kontrovers en die onderlinge Lutherse twiste geblyk dat die Heilige Skrif verskillend deur die teoloë uitgelê word. Daarom kom 'n tweede maatstaf na vore. Die argument ten gunste van die tweede maatstaf is dan

- die Heilige Skrif is en bly die enigste norm;

- die Augsburgse Geloofsbelydenis en die Apologie kom volkome met die Heilige Skrif ooreen;

- daarom, indien 'n mens binne die grense van die regte verstaan van die Heilige Skrif bly, bly mens vanself ook binne die grense van die belydenisskrif;

- daarom kan die belydenisskrif as omskrywing van die regula fidei en as norm van die ware leer geld.

Die uitgangspunt is dat die Heilige Skrif die enigste, absolute norm is om vas te stel wat die regte, ware leer is. Daarteenoor is die belydenisskrif ' $n$ genormeerde norm en daarmee word bedoel dat die belydenisskrif as ' $n$ maatstaf kan geld omdat dit self aan die oordeel van die Skrif onderwerp is.

So het in die kring van die Lutherse kerke die belydenisskrif 'n bepaalde omlynde posisie in verhouding tot die Heilige Skrif gekry en word dit so 'n norm waarmee die afwykende mening in die kerk getoets kan word.

\subsubsection{Die posisie in die Calvinistiese kerke}

As op die situasie in die Calvinisties-Hervormde kerke gelet word, kan gestel word dat net soos by Luther dit ook hier oor die algemeen beklemtoon is dat die Heilige Skrif die enigste en primêre bron vir die geloof en lewe is ${ }^{33}$. Dit word in die Tweede Switserse Geloofsbe- 
lydenis art 2 gestel. Omdat die belydenis so ' $n$ wye aanvaarding gehad het, is dit miskien goed om op die volgende te let:

“Die apostel Petrus het gesê: “... geen profesie in die Skrif kan op grond van eie insig reg uitgelê word nie (II Pet 1:20). Daarom laat ons ook nie allerlei soort uiteensettings (interpretationes) toe nie. ... ons erken alleen daardie uitleg van die Skrifte as ortodoks en eg wat uit die Skrif self geneem is ... en ooreenstem met die reël van die geloof en die liefde en wat duidelik die eer van God en die redding van die mens dien.

Daarom, in dispute oor die godsdiens of oor geloofsake, kan ons geen ander regter as God self aanvaar nie deurdat deur die Heilige Skrif aangedui word wat waar is, wat vals, wat gevolg en wat vermy moet word. Daarom stem ons alleen saam met die oordeel van geestelike manne (spiritualium hominum) soos dit uit die Woord van God blyk."

Die regula fidei, so word dit reëlmatig gestel, is die Woord van God soos dit in die Heilige Skrif gegee is.

In hierdie verband kan ook op die mening van die kerkvader Joh Calvyn gelet word. In die Voorrede tot die Kategismus van Genève van 1545 stel hy:

"In die huidige verwarde en verdeelde toestand van die Christendom dink ek dat dit goed sal wees as daar openbare getuienisse bestaan waardeur kerke, wat hoewel hulle ver van mekaar geleë is, mekaar tog onderling kan herken omdat hulle in die leer van Chistus ooreenkom."

Dié leer van Christus word primêr in die Skrif gevind, maar tog is die kerklike belydenisskrif ook gesien as 'n samevatting van dié leer. In 1548 , in 'n uitvoerige skrywe aan Eduard Seymour, die Hertog van Somerset, voer Calvyn hierdie saak tog weer verder. In sy skrywe word dit duidelik dat Calvyn die gepredikte Woord waardeer as dié middel by uitstek wat die hervorming van die kerk moet deurvoer. Dit skep egter in Engeland probleme en dan sê hy ${ }^{34}$ :

"Wanneer ek die kwaliteit van die onderrig aanroer, doen ek dit om te beklemtoon dat die volk so onderrig moet word, dat dit so lewendig gedoen moet word dat hulle kan agterkom wat die apostel bedoel as hy sê (Heb 4:12) dat God se Woord 'n tweesnydende swaard is wat die gedagtes en gevoelens tot by die murg van die gebeente oopkloof. Ek sê dit, edele heer, omdat dit my wil voorkom dat daar min lewende prediking in die Engelse koninkryk is omdat die meeste (predikante) net toegelaat word om preke te lees ..." 
Dan behandel Calvyn die vraag hoe die dwaallering en die ligsinnigheid van vrydenkende geeste in die kerk beteuel kan word. Daarvoor bestaan daar, sê hy, 'n goeie en beproefde middel "wat God self vir ons aandui". Hy stel dan:

"Dit is, eerstens, dat daar ' $n$ samevatting van die leer moet wees wat almal moet verkondig. Alle kerklike ampsdraers en predikante moet onder eed verklaar dat hulle hierdie belydenis sal onderhou en niemand moet tot ' $n$ kerklike amp toegelaat word wat nie belowe het om hom aan hierdie afspraak te hou nie.

Verder is 'n gemeenskaplike leerboek vir die kinders en die ongeletterde volk nodig waardeur die goeie leer aan hulle toevertrou word sodat hulle self die leuens en weerleggings, wat miskien in teenstelling tot so 'n leerboek ingebring kan word, kan onderskei. Glo my, edele heer, die kerk van God kan nie sonder so 'n kategismus staande bly nie, want dit is terselfdertyd die goeie saad wat sorg dat die goeie gesaaide nie uitsterf nie, maar van geslag tot geslag vermeerder word. ...

Hierdie Kategismus kan dus vir 'n dubbele doel nuttig wees, naamlik om die volk alles te leer sodat hulle die prediking kan benut en hulle ook kan onderskei wanneer een of ander eiesinnige mens ' $n$ vreemdsoortige leer voordra. Tog dink ek dat dit goed en selfs noodsaaklik is om die predikante te verplig om ' $n$ bepaalde, skriftelike vorm van die leer te aanvaar sowel om die gebrek aan kennis en eenvormigheid by sommige te hulp te kom as om ook die ooreenstemming en eenheid van alle kerke beter tot uitdrukking te bring, en, in die derde plek, om alle nuwighede en nuuskierigheid van predikante, wat alleen maar iets besonders na vore wil bring, in die kiem te smoor. Soos reeds gesê, vir dergelike mense moet die kategismus as 'n teuel dien."

Hierdie metode gee Calvyn aan die hand omdat hy met ' $n$ beroep op Jesaja 11:4 daarvan oortuig is dat die hervorming alleen kan seëvier en standhou as Jesus Christus en sy evangelie reg verkondig word want die viva vox evangelii is "die geestelike swaard van God se Woord".

Hier word dus aan die geloofsbelydenis ' $n$ bepaalde funksie in die kerklike lewe toegeken en dit is om te voorkom dat daar' $n$ dwaalleer in die kerk verkondig sal word. In Genève self het vanaf 1541 die reël gegeld $^{35}$ :

“Om elke gevaar te vermy dat die kandidaat (vir die diens van die Woord) een of ander dwaalleer aanhang, sal van hom 'n belofte geëis word dat hy hom aan die leer, wat die kerk 
goedgekeur het, sal hou. Hier sal die inhoud van die Kategismus (= die belydenisskrif van Genève) normatief wees."

Daarby moes alle Geneefse predikante om hulle "suiwerheid van en die ooreenstemming met die leer" te bewaar, weekliks bymekaarkom om die Skrif te bespreek, terwyl daar ook elke jaar, om die suiwerheid van die leer van elke predikant te bepaal, ' $n$ visitasie by hom gehou sou word. Tog bly die regula fidei nog steeds "die suiwer evangelie" en dit beteken nie primêr die belydenisskrif nie.

In hierdie verband is dit miskien tog interessant om op 'n duidelik teenstellende argument te let. Dit is van Zacharias Ursinus 1543-1583. Soos bekend was hy 'n mede-opsteller van die Heidelbergse Kategismus saam met Caspar Olevianus en as teologiese professor te Heidelberg het hy groot bekendheid geniet. In sy traktaat oor die belydenisskrifte stel hy 'n standpunt wat later in Nederland ook met groot instemming deur Jacob Armijn aangehaal is in sy twis met Frans Goemaere. Ursinus stel ${ }^{36}$ :

"'n Belydenisskrif is geen norm van die regula fidei waarvolgens 'n mens kan oordeel en sê wat 'n mens glo en aanvaar of wat' $n$ mens verwerp en veroordeel nie, wat waarheid of leuen, suiwer of ketters is nie. Immers dit is nie altyd waar wat met die belydenisskrif van die kerk ooreenstem nie en dit is ook nie altyd vals of verkeerd wat nie daarmee ooreenstem nie. Daarom kan mens nie verwag dat alle kerke die belydenisskrif van ' $n$ bepaalde kerk moet onderskryf nie.

Daarom is die belydenisskrifte nie net onderworpe aan die beoordeling en toetsing van ander kerke nie, maar ook van die kerke wat die belydenis opgestel het èn van hulle wat in die laasgenoemde kerke leer en lewe. Indien daar dan 'n tekortkoming in die belydenisskrif gevind word, kan hulle dit hoor, kennis daarvan neem en dit beoordeel. Indien iets dan gevind word wat verbeter moet word, kan dit met algemene instemming en in opdrag van die kerk, wat die belydenisskrif uitgegee het, verbeter of verklaar word ....

Aan die ander kant moet mens vir te veel knegskap en slawerny oppas sodat nie een of sommige kerke aan al die kerke, na hulle goeddunke 'n belydenisskrif voorskryf en dan almal veroordeel wat daardie belydenisskrif nie aanvaar nie."

Dié opvatting van Ursinus kan egter nie as die algemeen aanvaarde opvatting in die Calvinistiese kerke beskou word nie. Daarvoor kan byvoorbeeld verwys word na art. 1 van die Tweede Skotse Geloofsbelydenis van 1580 wat pertinent stel: 
"That this only is the trew Christian Faith an Relgion, pleasing to God, and bringing salvation to man quhilk is now, be the mercy of God, revealed to the warld be the preaching of the blessed Evangell; and is received, believed and defendit by mony and sundrie notabil kirkes and realmes. ... as Godis eternal trewth, and only ground of our salvation; as mair particularlie is expressed in the Confession of our Faith, stablished and publickly confirmed by sundrie Actis of Parliaments .... To the quhilk Confession and forme of Regligion we willingly agree in our consciences in all pointis, as unto Godis undouted trewth and veritie, grounded upon his written word."

Hier word die belydenisskrif duidelik gesien as die regula fidei wat die samevatting is van die essensie van die evangelie. Tog bly dit waar dat in die algemeen in die Calvinistiese kerke die regula fidei in die eerste plek die Skrif self is ${ }^{37}$.

Oor wat presies onder die regula fidei verstaan moet word, kan miskien die beste verwys word na die Nederlandse Geloofsbelydenis, art. 7 wat stel:

"Ons glo dat hierdie Heilige Skrif die wil van God volkome bevat en dat alles wat die mens moet glo tot saligheid, genoegsaam daarin geleer word. Aangesien die hele wyse van die diens wat God van ons vereis, daarin uitvoerig beskrywe is, mag ook niemand, selfs nie die apostels nie, anders leer as wat ons reeds deur die heilige Skrif geleer word nie. ...

Ons mag geen geskrifte van mense, hoe heilig die mense ook al was met die goddelike Skrif gelykstel nie; ook mag ons nie die gewoonte of die groot getalle of oudheid op opvolging van tye en persone of kerkvergaderingsbepalings en -besluite gelykstel met die waarheid van God nie, want die waarheid is bo alles."

en in art. 13 bely ons:

“... ons is ook tevrede daarmee dat ons leerlinge van Christus is om slegs te leer ken wat $\mathrm{Hy}$ aan ons in sy Woord openbaar, sonder om die grense daarvan te oorskry."

Die Skrif is die primêre en steeds die normerende norm. Maar omdat die regte prediking van die evangelie so lewensbelangrik is, kry die belydenisskrif, die kerk se antwoord op God se Woord, tog 'n bepaalde funksie in die kerklike lewe en ten opsigte van die prediking. Die saak wil ons 'n oomblik, veral in die Nederlandse situasie, van naderby besien. 


\section{DIE POSISIE VAN DIE GELOOFSBELYDENIS IN DIE NEDERLANDSE KERK}

In die Nederlandse Calvinistiese kerk het die aangeleentheid van die belydenisskrif, sy gesag en sy verhouding tot die Heilige Skrif ook aan die orde gekom. Dié saak is vir ons, vanweë die historiese bande met Nederland, wel belangrik genoeg om 'n bietjie tyd en aandag daaraan te wy.

Die eerste belydenisskrif wat in die Nederlandse kerk ontstaan, is die Nederlandse Geloofsbelydenis wat in 1561 deur Guido de Brès opgestel word. Dié Geloofsbelydenis is nie deur'n kerklike vergadering van die ampte opgestel nie maar deur De Brès, 'n predikant van die vervolgde Nederlandse kerk. De Brès stel hierdie belydenis saam met ' $n$ skrywe aan koning Filips II van Spanje op om die koning te oortuig dat die Calviniste niks anders as die Bybelse waarheid vashou nie. By die opstel van sy stuk het De Brès die Franse Geloofsbelydenis van 1559 gevolg en verwerk. Tog was die belydenis nie net die werk van een man nie. Adrianus Saravia 1530-1612, Waalse predikant te Kortrijk en later ook teologiese professor te Leiden, skryf hiervan ${ }^{38}$ :

"... ik beken, dat ik een geweest ben van de eerste opstellers dier Belijdenis, gelijk ook Herman Modet; ik weet niet of daar nog meer overig zijn. $\mathrm{Zij}$ is eerst geschreven in de Fransche taal door Christus getrouwen knecht en martelaar Guido de Bres; maar eer zij uitgegeven werd heeft hij dezelve aan de Dienaars des Goddelijken Woords, die hij heeft kunnen bekomen, medegedeeld en stelde het aan hem te verbeteren, zoo hun iets mishaagde, ook daar toe of af te doen: zoo dat zij niet moet gehouden worden voor het werk van een man."

Hierdie belydenis het baie gou 'n amptelike, kerklike karakter gekry. Reeds in 1563 besluit ' $n$ provinsiale sinode dat alle ampsdraers die geloofsbelydenis moet onderteken ${ }^{39}$ en in 1565 besluit die sinode van Antwerpen ${ }^{40}$ :

"By die aanvang van elke sinodesitting moet die geloofsbelydenis van die kerke van hierdie land gelees word sodat ons eenheid daaruit sal blyk en om te besluit of iets daarin verander of bewysig moet word."

Hier is daar nog nie sprake daarvan nie dat die belydenis anders funksioneer as om die eenheid in die leer onder woorde te bring nie. Hier geld die Heilige Skrif as die regula fidei en die belydenisskrif het nie daardie karakter nie. Selfs by die Convent van Wezel 1568 is 
dit opvallend dat ten opsigte van die proponentseksamen gestel word in art. $18^{41}$

"Daarna zal men hem afvragen of hij in alles overeenkomt met de leer die in de kerk opentlijk wordt onderhouden en vervat is in de belijdenis ... gelijk ook in de Catechismus."

Hoewel die belydenisskrif hier miskien as regula fidei of as samevatting van die leer van die Heilige Skrif beskou word, funksioneer dit nog nie as 'n norm en reël van die prediking of die leer in die kerk nie. Immers, so word in art. 22 gestel, die nuwe dienaar van die Woord mag alleen bevestig word nadat hy in die gemeente verklaar het:

"... hij in zijne dienst zal beoogen en betrachten de verbreiding van de eer Gods, de zuivere bediening Zijns Woords en de stichting Zijner gemeente."

Opmerklik is by Wezel dat daar nog nie voorsiening gemaak word vir die ouderling wat 'n besondere opdrag het om oor die kwaliteit van die prediking te waak nie. Dit kom eers later skerper na vore as die invloed van die Calvinistiese kerkordelike denke verder deurwerk.

Met die nasionale sinode van Emden 1571 is daar weer sprake van 'n ondertekening van die belydenis, maar dit gebeur meer "om de eendrachtigheid in de leer tusschen de Nederlandsche kerken te bewijzen". Daarom word ook die Franse Geloofsbelydenis onderteken "om daarmede haar verbinding en enigheid met dezelve Franse kerken te betuigen"42: Baie duidelik funksioneer die belydenisskrif hier om die eenheid in die geloof tot uitdrukking te bring. Daarom moes ook, volgens art. 4 van die kerkorde, alle aankomende predikante die belydenis met hulle handtekening onderskryf.

Hier is nog geen bepaling waarvolgens die belydenisskrif gebruik word as 'n norm om die suiwerheid van die leer te toets nie of as ' $n$ kontrole oor die kwaliteit van die prediking nie. Daarom word daar ook nie voorskriftelik opgetree ten opsigte van die inhoud en omvang van die leerstof wat by die kategese gebruik moet word nie. Die Geneefse en die Heidelbergse Kategismus word aanbeveel "doch alzo, dat of er in enige kerken een andere forme van Katechismus (den Woorde Gods gelijkvormig zijnde) gebruikten, die zullen te veranderen niet gedwongen worden." Die Heilige Skrif funksioneer nog as die enigste regula fidei en die belydenisskrif en die kategismus is aanvaar- en bruikbaar in die kerk omdat dit uitdrukking van die geloof, wat op die Skrif gebou word, is.

Die ondertekening van die geloofsbelydenis word in 1574 deur die provinsiale sinode van Dordrecht en in 1578 deur die nasionale 
sinode van Dordrecht uitgebrei sodat ook die ouderlinge, diakens en onderwysers die belydenisskrif moet onderskrywe. Andermaal is die motief "om eendrachtigheid in de leer te betuigen" (art. 53) ${ }^{43}$. By die bevestiging van 'n predikant in die amp kom die belydenisskrif ook nog nie ter sprake nie, want dan word slegs van hom verwag om instemmend op die vraag te antwoord wat as volg lui ${ }^{44}$ :

"Of zij de Heilige Bijbelse Schrift voor het enige Woord Gods en de volkomen leer der zaligheid houden, en alle ketterijen, daartegen strijdende, verwerpen?"

Die belydenisskrif, afgesien van sy kategetiese gebruik, funksioneer dan in die kerk hoofsaaklik as 'n saambindende getuienis. Die sorg vir die regte predikant van die Woord word aan die dienaar van die Woord oorgelaat, terwyl die ouderling oor sy dienswerk opsig moet hou. Die klassikale vergadering kom ook wel hier na vore in dié sin dat die vergadering, deur middel van sy opsig, moet sorg dra dat daar geen twyfel oor die leer in die gemeente ontstaan nie. Die regula fidei, die norm waarmee gemeet word, is nog steeds die Heilige Skrif self.

Vanweë die feit dat almal in die kerk deur middel van die kategismus in die hoofsom van die leer onderrig is, is die opvatting dat die afwykende mening maklik genoeg geïdentifiseer kan word. Daarby trek die belydenisskrif duidelik genoeg die grense van die kerk.

Dit sou egter nie so bly nie. In Nederland het daar geleidelik in die Calvinistiese kerk spanninge opgebou tussen die twee groot teologiese denkrigtings in die kerk. Dit het saamgegaan met die voortgaande stryd teen die Roomse leer, want hoewel die Kerkhervorming in Nederland begin seëvier vanaf die tagtigerjare van die 16de eeu, het dit nie beteken dat die aanhangers van die Roomse leer almal met die Hervorming saamgegaan het nie $\mathrm{e}^{\mathbf{4}}$. Terselfdertyd het die Calvinistiese meerderheidsparty in die kerk in botsing geraak met die ander groot stroming in die kerk wat hulle ook vir'n hervorming beywer het, maar dan nie volgens die Calvinistise opvattings nie. Reitsma teken die prentjie as volg ${ }^{45}$ :

"Met taaie volharding heeft het Calvinisme de kamp gevoerd voor een kerkorde, leerstelsel, kerkelijke tucht en gebruiken naar zijn opvatting met uitsluiting van elke andere zelfstandige overtuiging. Doch niet zonder krachtig verzet kreeg het de overhand, ook niet zonder harde slagen der teleurstelling. Het beleefde tegenstand van vele zijden, om verschillende redenen. Er kwam wrijwin niet alleen met hen, die een ander maatstaf van Christelijk geloof begeerden dan de door Genève als onfeilbaar gestempelde leer, maar ook met dezulken die op burgerlijk 
en staatkundig gebied neit geliefden te buigen onder het juk der kerkelijken.

Het ganse kerkelijk-staatkundig verschil in deze ingewikkelde periode van onze geschiedenis kan worden herleid tot twee hoofdpunten: de bepaling der verhouding van de kerk tot de staat en de bepaling van het gezag der belijdenisschriften, derhalve over kerkorde en confessie."

Geleidelik, vanaf die negentigerjare van die 16de eeu word die stryd tussen die Calviniste en die "nasionaal-gerformeerdes", wat uit die kring van die Bybelse humaniste en sakramentariërs na vore gekom het, al skerper. Dit word 'n magstryd in die kerk en dit gaan om die vraag of die Calvinistiese leer, lewenspraktyk en kerklike ordening sal seëvier of dat die sogenaamde rekkelijkes die toon sal aangee. In hierdie stryd word die belydenisskrif as samevatting van die hoofsom van die Christelike leer, gebruik as die norm, die maatstaf waar, reg of verkeer, waar of vals, ortodoks of ketters bepaal kan en moet word. Nou is die belydenisskrif en die instemming daarmee nie meer primêr die teken van die eenheid in die geloof nie, maar dit word 'n soort magsmiddel. Daarom word die vraag in dié stryd ook akuut hoe die belydenis onderteken word en wat daardie ondertekening presies beteken.

Soos reeds aangedui is die belydenisskrif aanvanklik mondeling bevestig en daarna slegs deur die handtekening onder 'n uitgawe van die belydenisskrif te plaas ${ }^{46}$. In 1578 word dan egter op die provinsiale sinode van Suid-Holland 'n ernstige debat gevoer oor die ondertekening van die belydenisskrif. Dit dan in dié sin dat die ondertekening nie net geld om die eenheid ten opsigte van die leer uit te druk nie, maar veral om die suiwerheid van die leer te bevestig. Daarby is dan ook gestel dat 'n klassikale vergadering die bevoegdheid moet hê om met 'n predikant te handel indien daar bedenkinge teen sy regsinnigheid sou ontstaan ${ }^{47}$. Die nasionale sinode van Middelburg 1581 het nie op hierdie sake ingegaan nie sodat die status quo voorlopig nog voortgeduur het ${ }^{48}$. Die nasionale sinode van Den Haag 1586 voer die saak egter verder as hulle 'n bepaalde sanksie verbind aan die nie-ondertekening van die belydenisskrif. In art 47 word dan gestel ${ }^{48}$ :

"De dienaars des Woords, idem de professoren in de theologie ... zullen de belijdenis des geloofs der Nederlandse kerken ondertekenen. En de dienaars die zulks zullen refuseren, zullen de facto van hun dienst bij de kerkeraad, of classe opgeschort worden, ten tijd toe zij zich daarin geheellijk verklaard zullen hebben, en indien zij obstinatelijk in weigering blijven, zullen van hun dienst geheel afgesteld worden." 
So kom geleidelik ' $n$ verdere gebruik van die belydenisskrif na vore, veroorsaak deur die botsings op leerstellige vlak binne die kerk. Dit lê in die lyn van Calvyn se advies aan Somerset in 1548 waarvolgens die belydenisskrif die maatstaf word waarmee die leer beoordeel word. Die belydenisskrif word so 'n formulier met bindende gesag soos die klem al meer, vanweë die leerstellige stryd, verskuif na die regte leer en al die klem nie meer lê op die regte verkondiging van die evangelie van Jesus Christus nie.

In sekere sin hang dit ook saam met die verskuiwing van die kerk as 'n dinamiese en lewende geloofsgemeenskap. Daarvolgens is die regte prediking van die evangelie van primêre belang waarop, volgens Calvyn, die regte hoor en uitleef van die verkondigde Woord moet volg. Daardie regte prediking en die regte hoor van die evangelie staan voortdurend onder die opsig van die ouderling en die kerkraad wat die maatstaf van enige regula fidei, die Heilige Skrif, gebruik in die beoordeling.

Maar soos die kerk al meer verstaan word as 'n geïnstitueerde gemeenskap met 'n vaste orde en reël en die juridies-institutêre op die voorgrond tree, is dit ook verstaanbaar dat daar na 'n makliker hanteerbare maatstaf en norm vir die regte prediking en dan ook die regte leer, wat agter die prediking staan, gesoek sal word. Dit is dan ook nie so vreemd dat die belydenisskrif dan na vore kom nie. Reeds Calvyn se opvolger, Theodorus Beza 1519-1605, het in hierdie rigting beweeg as hy hom beroep op Augustinus se De doctrina christiana waar gestel word dat die Skrif uitgelê moet word volgens sy eie betekenis en in samehang met die geloofsartikels ${ }^{49}$. Beza stel dan ook dat die vroeë kerk juis die geloofsbelydenis, geput uit die Skrif, opgestel het sodat daar tussen ortodokse en ketters onderskei kan word $^{50}$. So bestaan daar tendense binne die Calvinisme wat die verskuiwing van die verstaan van die kerk in die rigting van die institutêr-juridiese bevoordeel het. Deur die vasstelling van die belydenisskrif as die norm en die maatstaf van die regte leer en die prediking word 'n makliker hanteerbare reël as die Heilige Skrif self gegee. Die argument is dan dat die belydenisskrif volkome met die Skrif ooreenkom, want dit is uit die Skrif geneem en as sodanig is dit ondergeskik aan die Skrif, dit is 'n genormeerde norm. Wie dus binne die raamwerk van die belydenisskrif bly, bly binne die raamwerk van die Skrif. Tog bestaan dan die wesenlike gevaar dat die belydenisskrif, juis vanweë sy makliker hantering as norm, of langs of bo die Skrif verhef kan word.

Die gedagte om dan verder ' $n$ bepaalde formule op te stel waarin presies bepaal word hoe die belydenisskrifte onderteken word, is dan in hierdie klimaat volkome vanselfsprekend. Dit word die eerste maal deur die klassis Alkmaar gestel en deurgevoer ${ }^{51}$. Daarna het 
ander klassikale vergaderings dit ook ingevoer. Op die provinsiale sinode van Overijssel van 1612 word besluit ${ }^{52}$ :

"Updat die einicheit der kerke ende insonderheit die sueverheit der lehre in diesen lande, gelick tott nog Godtloff geschiet is, moge underhouden worden, so ist dat van einen ijder int besonder gevraget, off hij ock etwas hadde tho seggen tegen den Cathechismum ende Nederlandische Confessie, gelick dieselvigen tott noch in die kerken dieser lande zin onderhouden, sonder einige niuwe glossen darbij tho doen. So hebben sij einpaarlicken geantwordet: neen."

Die volgende jaar het die provinsiale sinode van Groningen 'n formule opgestel, waarskynlik in navolging van die provinsiale sinode van Zeeland wat reeds in 1610 so ' $n$ ondertekeningsformule opgestel het ${ }^{53}$. Duidelik gaan dit vir dié sinode om die "suijverheyt der leere" en daarom word in die formule gestel dat die ondertekenaar

"alle de artyculen ende leerstucken, die in dese Nederlandtsche Confessie oft belydinge in 37 articulen begrepen und in desen chrsitlicken Heijdelberschen Catechismo ... in alles met Goddes $h$ wort overeincommen und het fondament der eniger leer der zaligheijt in sich begrijpen."

Die formulering van Zeeland verskil nie wesenlik hiervan nie en so word dit ook in die Dordtse ondertekeningsformulier wat in 1619 opgestel word, deur die nasionale sinode aanvaar ${ }^{54}$. Hiermee word in 'n sekere sin die belydenisskrifte tog op dieselfde vlak as die Skrif gestel so lank die teendeel nie, deur middel van 'n gravamen wat deur ' $n$ sinodale vergadering beoordeel moet word, bewys is nie. Opmerklik is dat met die Dordtse formule ook beloof word:

"... dat Wy de voorseyde Leere neerstelyk sullen leeren en getrouwelijk voorstaan, sonder yet tegen deselve leeren ... te leeren of te schrijven."

Met ander woorde dit gaan om die leer soos dit in die belydenisskrifte vervat is en nie juis om die belydenisskrif se spesiale uitdrukking van die leer nie.

Deur middel van hierdie "accuraat formulier" en vanweë die hulp wat van owerheidsweë verleen is, is die kettery van die remonstantisme uiteindelik uit die kerk geweer en verwyder.

Augustijn, as hy hierdie ontwikkeling in oënskou neem, wys op 'n bepaalde ontwikkeling in die plek en posisie van die belydenisskrif in die Calvinistiese kerk $^{55}$ : 
1. Oorspronklik is die belydenisskrif 'n verklaring van geloof, 'n verklaring van hoe die Heilige Skrif op bepaalde punte verstaan word. Op daardie stadium is die belydenisskrif vir die eie kring bedoel.

2. Dan word die belydenisskrif vollediger en meer teologies van aard. So word die belydenisskrif 'n samebindende getuienis wat terselfdertyd ook gerig is op die medegelowiges en die buitestaanders.

3. Ten slotte word die belydenisskrif ' $n$ middel om die kerk te beskerm teen kettery binne die kerk self. Dan word die belydenis die duidelike omskrywing van die grense van die kerk. So word die belydenisskrif, ook as norm en reël van die prediking, die kort saamgevatte regula fidei.

Die hele verhouding Skrif en belydenis word veral deur die ondertekeningsformule wat aan die kandidaat vir die diens van die Woord voorgelê word, duidelik uitgespel. Daarvolgens funksioneer die belydenisskrif as 'n genormeerde norm van die leer en geloof in die kerk. Met sy handtekening onder die ondertekeningsformule aanvaar elke predikant hierdie uiteensetting en so maak hy dit self 'n saak wat op hom betrekking het. Daarby aanvaar elke predikant wat die formule onderteken dat as hy oor hierdie bepaalde verhouding van Skrif en belydenis of oor die verklaring dat die leer van die belydenisskrifte in alles met God se Woord ooreenkom, beswaard voel hy dié besware by wyse van $\mathrm{n}$ geskrewe stuk aan die bevoegde kerklike vergadering van die ampte sal voorlê sodat die aangeleentheid daar hanteer kan word.

Dit is duidelik dat die kerk, vanweë die sonde van die mens, gedwing was om die belydenisskrif as ' $n$ beskermmiddel teen ketterye in die kerk in die orde en lewe van die kerk te gebruik. Uit die manier waarop die norm en reël wat die belydenisskrif nou is deur die kerklike vergadering van die ampte hanteer word, sal wel blyk of die belydenisskrif in die kerk as 'n genormeerde norm hanteer word of nie. Daarom kan, as 'n uitleg van die bedoelinge van die Dordtse sinode van 1619, nog 'n oomblik gelet word op die uitspraak van Amoldus Thysius in die beroemde Dogmatiek-handboek, die Synopsis Purioris Theologiae wat in 1625 verskyn het. Daar stel hy ${ }^{56}$ :

"De norm echter en de regel van deze handeling en van het Synodaal oordeel, moet geheel en al, alleen en onweersprekelijk zijn het woord van God in die Schrift vervat (Matt 2:5; Hand 15:14) welke ook door haar duidelijkheid de Rechter genoemd kan worden (Joh 5:45). ... Net echter geschriften en gezegden buiten deze, hoedanig ook, hetzij private, hetzij publieke, zijn norm of vorm der waarheid, maar slechts vorm van oordeel en overeenstemming der kerk." 
Dit bring ons dan in die historiese oorsig tot by die $17 \mathrm{de}$ eeu en dan kan, net kortliks, ook nog gelet word op die 18de- en 19de-eeuse situasie in Nederland.

\section{SKRIF EN BELYDENISSKRIF IN DIE 19DE EEUE NEDERLANDSE HERVORMDE KERK}

Met die deurwerking van die denkbeelde van die Verligting in die Nederlandse kerk gedurende die 18de en 19de eeu het daar 'n geweldige verskuiwing gekom in die hele verstaan van die verhouding van die Skrif en die belydenisskrif in die lewe en orde van die kerk. Allereers is die proponentsformule, soos dit by Dordt 1619 vasgestel is, in die Reglement op het Examen van 11 Julie 1816 so gewysig dat dit nou gelui het dat die ondertekenaar ${ }^{57}$

"... verklaren bij deze opregtelijk ... dat wij de leer, welke overeenkomstig Gods Heilig Woord, in de aangenomen formulieren van eenigheid der Nederlandse Hervormde Kerk is vervat, ter goeder trouw aanneemen en hartelijk geloven ..."

In hierdie formulering was daar 'n paar voetangels. In die eerste plek het die omskrywing "de aangenomen formulieren van eenigheid" ' $n$ vraagteken oor die Dordtse Leereëls gestel omdat dit nie oral deur al die provinsiale sinodes in die 17 de eeu aanvaar is nie.

Die tweede probleem het gelê in die formulering: “... de leer, welke overeenkomstig Gods Heilig Woord, in de aangenomen formulieren van eenigheid ... vervat is". Hier ontstaan die vraag of die leer van die belydenisskrifte aangeneem word omdat (quia) hulle met die Woord van God ooreenstem of vir sover (quatenus) hulle ooreenstem. Die Dordtse formule het baie duidelik 'n quia-standpunt gestel en hier word die indruk geskep dat ruimte vir'n quatenus-standpunt geskep is ${ }^{58}$. Dit was ook korrek, want in 1841 het die Generale Sinode beslis dat die quatenus-standpunt die enigste aanvaarbare kan wees $^{59}$. Daarom is die ondertekeningsformule in 1854 gewysig sodat dit gelui het:

"dat wij des zins en willens zijn den geest en de hoofdzaak der leer, welke in de aangenomen formulieren van eenigheid der Nederlandsche Hervormde Kerk begrepen is, getrouw te handhaven."

In hierdie formule word die belydenisskrifte nog genoem, maar in die opvolgende wysiging van 1888 is die verwysing na die formuliere van enigheid heeltemal weggelaat ${ }^{60}$. Terselfdertyd is die Reglementen so opgestel dat daar geen moontlikheid was om in die Neder- 
landse kerk enige vorm van leertug toe te pas nie. Hoewel art. 9 van die Algemeen Reglement aan die sinode die "handhaving der leer" opgedra het, is die Reglementen so geformuleer dat nêrens 'n verband tussen "de leer" en die belydenisskrifte gelê kan word nie. Slegs die Heilige Skrif is as norm en reël van die geloof en lewe aanvaar. Nadat die teoloë van die Groninger Rigting en die Moderne Teologie egter met die Skrif "klaar" was, het daarvan ook nie meer veel oorgebly nie. Dit het beteken dat, volkome in lyn met die opvattings van die Verligting, die enkeling, die indiwiduele predikant self en alleen moes uitmaak wat hy wil preek en wat nie. Geen mens, geen ampsdraer en geen kerklike vergadering van ampsdraers kon 'n predikant tot orde roep oor die kwaliteit van sy prediking nie. Selfs die Bybel kon nie as norm gebruik word nie, want volgens Scholten is die Bybel nie die grondslag nie maar hoogstens die uitdrukking van die geloof van ' $n$ Christen ${ }^{61}$. Geen wonder dat JI Doedes in 1854 al gestel het ${ }^{62}$ :

"De Confusie komtin plaats van de Confessie. Niet de afwijking van de belijdenis der Kerk, maar het ijveren voor de handhaving dier belijdenis wordt ketterij, en die het minst gunstig voor de leervrijheid en de met haar ongebreidelde vrijzinnigheid gestemd zijn, moeten noodwendig voor die gevaarlijkste en meest zorgwekkende leden der gemeente gehouden worden."

So het in die Nederlandse Hervormde Kerk in die 19de eeu totale leervryheid in die plek van die handhawing van die leer gekom en is die belydenisskrifte volkome op die agtergrond van die kerklike lewe geskuil. Die leervryheid het die kerk as getuie van Jesus Christus totaal verlam. Hoewel daar ' $n$ manhaftige poging aangewend is om die agteruitgang reg te stel, kon die kerk nog nooit weer die leertug laat funksioneer nie. Die eindresultaat is dat, oor die algemeen gesproke, die Nederlandse kerk vandag oor baie dinge getuig en verklarings maak behalwe oor Jesus Christus, die gekruisigde en opgestane Heer. Die Nederlandse kerk is dan ook 'n pragtige voorbeeld van wat met ' $n$ kerk in die wêreld gebeur as hy die regua fidei nie meer kan of wil handhaaf nie. Dan is nie meer die evangelie van Jesus Christus van die Skrifte die saak waarom die gaan nie, maar willekeur, eiesinnigheid en hoogmoed van die sondaar-mens.

\section{6. 'N PAAR KURSORIESE OPMERKINGS OOR SKRIF EN BELYDENISSKRIF IN ONS KERK}

Aangesien hierdie saak deur die opvolgende referaat uitvoerig behandel sal word, word hier net 'n paar opmerkings ter afsluiting 
gemaak. In ons kerklike verlede het van 1652-1804 die situasie gegeld dat alle predikante vir ons Kerk in Nederland geëksamineer is, daar die proponentsformule onderskryf het wat vir die klassis Amsterdam en die sinode van Noord-Holland gegeld het.

In 1804 het Kommissaris-Generaal JA de Mist deur middel van 'n ordonnansie ' $n$ nuwe bedeling vir die kerk aan die Kaap geskep. In hierdie ordonnansie maak De Mist geen bepalings oor die leer van die kerk nie maar laat dit in die hande van die kerk self.

Hierdie owerheidsreëling het vir die kerk aan die Kaap die geleentheid geskep om tot 'n selfstandige organisasie te groei en om ook ' $n$ eie, meerdere vergadering in te stel. Dit gebeur in 1824 as die eerste sinodale vergadering in Kaapstad gehou word en daar dan 'n Algemene Reglement voor het bestuur der Nederduitsch Hervormde Kerk in Zuid-Afrika opgestel word. In die Reglement word nie 'n proponentsformule opgeneem nie omdat die moontlikheid nog nie voorsien word dat die kerk self voornemende predikante sou toelaat nie. Die proponentsformule wat in uitvoering van art 21 van die Reglement opgestel is, het 'n duidelike quia-standpunt gehad en het o.a. gelui ${ }^{63}$ :

"... dat wij van harte geloven dat al de artikelen en stukken der Leer in de Belijdenis en catechismus, zijnde de Formulieren van Eenigheid der Gereformeerde Kerken van Nederland begrepen, met Gods Woord overeenkomen: Wij beloven voorzeide Leer naarstig te zullen leeren, en in onzen wandel getrouw te zullen handhaven ..."

Hier funksioneer die belydenisskrif duidelik as 'n regula fidei.

In die Ned. Hervormde Kerk in die ou ZAR is daar aanvanklik nie 'n proponentsformule in die Reglementen van 1862 opgeneem nie. Met die koms van ds NJ van Warmelo na die ZAR moes so 'n formule opgestel word omdat hy sy aansoek tot legitimasie by die Kaapse kerk teruggetrek het. Die formule kom dan in art 41 van die Reglementen van 1869 voor. Dit is dieselfde formule wat tot vandag toe nog gebruik word en verteenwoordig 'n duidelike quia-standpunt, veral vanweë die slotsin van die formule wat lui:

"Deur hierdie formule te onderteken, verklaar ek dat ek vas oortuig is en glo dat die leer wat in die formuliere van eenheid uitgedruk is, in volkome ooreenstemming met die Woord van God is."

Daar moet op gelet word, om 'n enkele oomblik van die suiwer historiese argument af te wyk, dat die ondertekenaar van hierdie formule wat in die lyn van die Dordtse formule lê, homself primêr bind aan die Woord van God en die regula fidei wat die Woord gee. 
Die belydenisskrif geld dus as die genormeerde norm omdat die belydenisskrifte, na die oordeel van die kerk en die ondertekenaar van die formule, met die Woord van God in alles ooreenkom. Daarom word die toegelate proponent ook na sy bevestiging in die amp 'n dienaar van die Woord wat die primêre opdrag het om die Woord te verkondig. Die belydenisskrifte, as genormeerde norm, dui die grense aan en is, na die stelling van Thysius, vorm van oordeel en overeenstemming der kerk. Daarom moet daar opgepas word dat die verkeerde voetspoor van Abraham Kupyer nie gevolg word nie. Hy het in die vorige eeu skerp teen die leervryheid in die Nederlandse Hervormde Kerk gereageer en het daarin die belydenisskrif as norm langs die Skrif en soms selfs bo die Skrif verhef.

Die kerkvader Joh Calvyn het ons geleer dat die regte verkondiging van die Woord, dit wil sê dié verkondiging waar die Skrif met behulp van die Skrif self uitgelê word, die volk van God in die geloof bou. Dit kan in die kerk nooit gaan om die verkondiging van ' $n$ leer nie, maar alleen van Jesus Christus, die gekruisigde en opgestane Heer. Daardie verkondiging kan deur die belydenisskrifte genormeer word, maar dan alleen omdat die belydenisskrifte, na die oortuiging van die dienaar van die Woord, met die Woord van God ooreenkom.

Die hele saak van die verhouding van Skrif en belydenisskrif word die eerste maal skriftelik in ons Kerk geformuleer in die KonsepReglement van 1857 waar art 9 soos volg lui:

"Beschuldigingen tegen de leer van een Predikant, zullen inhouden duidelyke bewyzen dat hy de leer, welke volgens Gods heilig Woord, vervat is in die aangenomen formulieren van eenigheid der Gereformeerde Kerk, heeft wedersproken of bestreden."

In beide formulerings is dit duidelik dat die regula fidei in die belydenisskrifte geformuleer is en dat daardie formulering in ooreenstemming met die Woord van God is. So is die belydenisskrif die genormeerde norm wat in die kerk paal en perk aan die afwykende mening stel.

Hoewel Augustijn die argument voer dat as die belydenisskrif so hanteer word, dit noodwendig tot belydenisdwang voer ${ }^{64}$, is dit nie vanselfsprekend nie. Alles hang daarvan af hoe die bevoegde kerklike vergaderings van die ampte in hierdie verband optree. Terwyl dit waar is dat in ons Kerk die leertug steeds konsekwent toegepas is, sonder dat daar ooit sprake van 'n ketterjag was, is dit uit die leertugsake wat gevoer is ook duidelik dat die afwykende mening altyd ook deur die primêre regula fidei, dit is die Skrif self, getoets is.

Opsommend kan gestel word dat die geskiedenis en dus ook hier- 
die kursoriese oorsig nie al die vrae en probleme wat hier bestaan, kan of wil oplos nie. Tog is die oorsig van die geskiedenis wel belangrik omdat dit beklemtoon dat ons probleme nie so danig nuut is as wat ons mag dink nie. Voor ons het eerbiedwaardige kerkvaders en teoloë ook al met hierdie saak geworstel en moes hulle beslissings neem, hoe moeilik dit soms ook al was. Daardie beslissings kan ons, met die perspektief wat ons deur die afstand gebied word, nou beoordeel.

Verder sal ons steeds, as ons oor hierdie saak van die verhouding van die Heilige Skrif tot die belydenisskrif en laasgenoemde se plek en funksie in die kerk handel, in gedagte moet hou dat ons met 'n sensitiewe saak te make het. Dit gaan immers hier oor die regte verkondiging van die Woord van God, dit gaan om die Woord self, dit gaan om die geloofsantwoord van die kerk, die gemeenskap van die gelowiges. Daarom soos van ons verwag word, moet die eer van God en die opbou van sy kerk in geloof en lewe voor oë gehou word as ons oor die hele saak van Skrif en belydenisskrif met mekaar gedagtes wissel.

\section{Aantekeninge}

1. Vgl. o.a. Mt 16:16-19.

2. H Bouwman, Gereformeerd Kerkrecht, Kampen 1970, D1 2, bl 555-6.

3. Vgl. in hierdie verband oa Ef 3:9 en 14; II Tim 1:10-14.

4. Die belydenis van die kerk word ook pertinent in art I van die Kerkwet en art XVIII genoem.

5. Bep 73.2. My beklemtoning.

6. Hand. 4:20: Wat ons betref, dit is onmoontlik om nie te praat oor wat ons gesien en gehoor het nie. Vgl. ook II Kor 4:13-15.

7. Ad von Harnack, Lehrbuch der Dogmengeschichte, Tübingen 1909, Bd I S 175 176.

8. F Loofs, Handboek voor de beoefening van de Dogmengeschiedenis, bewerkt door J Quast, Groningen 1902, bl 94-95. Sien ook W Bauer, Rechtgläubigkeit und Ketzerei im altesten Christentum, Tübingen 1964, S 300-301; vgl ook S $134 \mathrm{f}$.

Hier kan ook verwys word na die trinitariese doopbelydenis wat gevind kan word in die Epistola Apostolorum van ongeveer 150 waarin para 5 die belydenis voorkom: (Ons glo) in die Vader, die Heerser van die hele wêreld, en in Jesus Christus, ons Heiland, en in die Heilige Gees, die Parakleet, en in die heilige kerk en in die vergewing van die sonde.

Dergelike belydenisse kan ook gevind word by Irenaeus (130-200) Adv Haer 1. 10 en 4. 33. 23 en ook in die liturgie van die payrus Dêr Balyzeh.

Dat die geloofsbelydenis reeds vroeg in die godsdiensoefening gebruik word blyk daaruit dat reeds in die dankgebed by die viering van die eucharistie 'n taamlike uitvoerige Christusbelydenis voorkom, vgl Justinus, Apol I. 13. Vgl oa A Hahn = GL Hahn, Bibliothek der Symbole und Glaubensregeln der Alten Kirche, Hildesheim $1962, S 4$.

9. F Loofs, aw, bl 94.

10. Vgl A Hahn, aaO, s 1-20.

11. Justinus Martyr (100-165) lê al so 'n maatstaf aan oor wat as Christelik en wat as nie-Christelik nie beskou moet word, vgl sg Dial c Tryph, 63, 80, 85 ea waar hy die basiese elemente van die geloof omskryf. Dieselfde kan gevind word by Irenaeus, Aristides van Athene (2de eeu) in sy Apologie wat uit 140-145 dateer. 
12. Adv Haer 1.10.2; 3.3.1; 3.4.1. Irenaeus se standpunt kom daarop neer dat die fides apostolica omskryf moet word. Daarna word dit dan gebruik om alle leerverskille te beoordeel. So word die regula fidei of veritatis gebruik om die grens tussen die kerk se leer en die ketterse standpunt te trek.

13. Vgl oa De praescript haer c 13; Adv Prax 1-2.

14. Ad von Harnack, $a a O, S 364$.

15. Ad von Harnack, aaO, S 367.

16. So ook by Origines, $185-254$, in sy De Princip 1. 4-5.

17. Ad von Harnack, aaO, S 399-411.

18. Vgl B Altaner, Patrologie, Freiburg 1955, S 36-37; asook Ad von Harnack, aaO, S 511.

19. In sy De praescr haer noem Tertullianus die regula ook die gubernaculum interpretationis van die Skrif.

20. Vgl C Augustijn, Kerk en Belijdenis, Kampen 1969, bl 9 vg.

21. Daar kan ook verwys word na die Anglikaanse Kategismus van 1549 en 1662, die Westminster Kategismus en die Skotse Kategismusse, hoewel dié nie die status van belydenisskrif gekry het nie.

22. H Bornkamm, Das Augsburger Bekenntnis, Hamburg 1965.

23. C Augustijn, aw, bl 45-46.

24. Vgl in hierdie verband oa E Koch, Die Theologie der Confessio Helvetica Posterior, Neukrichen $1968, \mathrm{~S} 19 \mathrm{vg}$.

25. Reeds in 1518 stel Luther in sy Eine Freiheit des Sermons usw, eyn ketzer heyst, der nit glaubt die stuck, die nod und gepoten seyn zu glauben.

In 1580 stel hy ook: der ist eyn ketzer, der halstarrig in einem Artikel des Glaubens irret und das bekennet.

26. H Bornkamm, Das Jahrhundert der Reformation, Göttingen 1961, S22.

27. H Bornkamm, aaO, S 221: Auch auf die Confession Augustana wird noch keine eidliche Verpflichtung gefordert, sondern es wird nur auf sie ebenso wie auf andere Schriften, die keinen eigentlichen Bekenntnischarakter tragen, (wie Luthers Postillen oder Melanchtons Unterricht der Visitatoren) als Norm der geltenden und innezuhalten den Lehre verwiesen.

28. P Schaff, Creeds of Christendom, New York 1919, p 96-97. In die voorafgaande inleiding word 'n uiteensetting gegee van die reël en norm waarvolgens alle leerstellings beoordeel moet word. Die uiteensetting begin met die stelling (ek vertaal uit die Latyn): Ons glo, bely en leer dat die enigste reël en norm (nicam regulam et normam) waarvolgens alle leerstellings (omnia dogmata) en alle doktore geëvalueer en getoets behoort te word is hoegenaamd geen ander nie as die profetiese en apostoliese geskrifte sowel van die Ou as Nuwe Testament ....

Maar ander geskrifte, of dit nou van die vaders is of van moderne skrywers, ... mag op geen manier gelykgestel word met die Heilige Skrifte nie, maar moet almal as van mindere waarde ten opsigte van die Skrifte beskou word sodat hulle nie anders verstaan sal word as getuienisse nie om aan te toon watter leerstellings na die tyd van die apostels geleer is en ook in watter dele van die wêreld die gesonde leer van die apostels en profete beter bewaar is.

29. Die Lutherse belydenisskrifte wat hier genoem word is: Die Augsburgse Geloofsbelydenis en die Apologie, die Smalkaldiese Artikels van 1537 en Luther se Groot en Klein Kategismus.

30. C Augustijn, aw, bl 38-39.

31. Hier is gebruik gemaak van feite en opmerkings wat gegee word deur C Augustijn, aw, bl 38-39.

32. Vgl oa P Jacobs, Theologie Reformierter Bekenntnisschriften in Grundzugen, Neukirchen $1959, \mathrm{~S} 16$.

33. $\mathrm{Vgl}$ in hierdie verband die Confessio Helvetica Prior van 1536 wat stel in art 2: Diese heilige göttliche Schrift soll nicht anders, als aus ihr selbst ausgelegt und erklärt wurden durch die Richtschnur des Glaubens und der Liebe Uoh 5; Rom 12; I Kor 13). In art 5 word dan verder gestel: Die ganze biblische Schrift sieht allein darauf, dass der Mensch verstehe das ihm Gott gunstig sei und wohlwolle, und das er diese seine Guwilligkeit durc Christum, seinem Sohn, dem ganzen menschlichen Geschlecth öffentlich dargestellt und bewiesen habe, die aber allein 
durch den Glauben zu uns komme, allein durch den Glauben entfangen, und durch die Liebe gegen der Nächsten gezeigt und bewiesen werde.

So stel die Franse Geloofsbelydenis 1559, art 5: Ons glo dat die Woord wat deur hierdie boeke bevat word, van God uitgegaan het en dat dit sy gesag van Hom alleen kry en nie van mense nie. En omdat dit die reël van alle waarheid is wat alles bevat wat nodig is vir die diens van God en vir ons verlossing, is dit nie wettig vir mense of selfs engele om iets daaraan toe te voeg, of weg te neem, of te verander nie.

In die Nederlandse Geloofsbelydenis, art 7 word byna dieselde gesê. Vgl ook die Skotse Geloofsbelydenis 1560, art 20. Ook die 39 Articles 1563 van die Anglikaanse kerk stel in art 6 dieselfde saak, $n 1$ dat die Skrif self die regula fidei is. Interessant is dat ook die Westminster Confession 1647 wat gewoonlik as die laaste van die Calvinistiese belydenisskrifte beskou word, in art 2, nadat die lys kanonieke boeke van die OT en NT gegee is, stel: All which are given by inspiration of God, to be the rule of faith and life (fidei vitaque regulam). In art 10 word gestel: The Supreme Judge, by which all controversies of regligion are to be determined, and all decrees of councils, opinions of ancient writers, doctrines of men and private spirits, are to be examined, and in whose sentence we are to rest, can be no other but the Holy Spirit speaking in the Scripture Matt 22:29 en 31; Ef 2:20, Hand 28:25.

34. R Schwarz, Johannes Calv ins Lebenswerk in seinen Briefen, Neukirchen 1962, Bd 2, S 443-444.

35. AD Pont, Die Historiese Agtergronde van ons Kerklike Reg, Pretoria 1981, Dl 1, bl 23.

36. P Jacobs, $a a O, \mathrm{~S} 16$.

37. Miskien kan hier verwys word na nog twee van Calvyn se uitsprake. In sy Beknopte Geloofsbelydenis (Opgeneem by H Beveridge and TF Totrrance, Tracts and Treatises on the Doctrine and Worship of the Church by John Calvin, Edinburgh 1958, Vol 2, p 133): Ek glo dat sowel die hele reël vir die regte lewenswandel en ook die onderwysing in die geloof volledig in die Heilige Skrif gegee is ... Ek verwerp daarom ook alle menslike inbeeldinge wat hulle as geloofsartikels aan ons wil opdring en waarmee hulle ons gewetes deur wette en reëls wil bind.

In 'n Geloofsbelydenis wat Calvyn in 1562, namens die Franse kerk voorgelê het aan die keiser en vorste van Duitsland tydens die Ryksdag van Frankfurt, word in art 5 gestel: Aangesien ons die Ou en die Nuwe Testament as die enige reël van ons geloof hou, daarom aanvaar ons alles wat daarmee ooreenkom.

38. Joh Ens, Kort Historisch Berigt van de Publieke Schriften rakende de Leer en Dienst der Nederduitsche Kerken van de Vereenigde Nederlanden, Kampen 1857, bl 72 wys daarop dat Trigland in sy bekende Kerkelijke Historie, III, bl 145 sê: Dat onze voorzaten van de ou den, die onder de Kruiskerken verkeerd hebben, berigt zijn geweest dat Guido de Bres met goedvinden van zijn medehelpers in de Gemeenten van Rijssel, Casselrye, Doornik, Valenciennes, enz en $G$ van Wingen, met kennis van zijne mede-arbeiders in Vlaanderen, Brabant, Holland enz de eerste stellers van de Confessie zijn geweest.

Op grond hiervan stel Ens dan dat die manne wat die belydenis nagesien, beoordeel, verbeter en aanbeveel het die volgende predikante was: $C$ Fabritius, die martelaar, Korn Kooltuijn van Emden, $P$ Dathenus en $C$ van der Heijden van Frankenthal, Vallerandus Pollanus toe van Frankfurt, Joh Taffinus en $P$ Colonius van Metz, N Gallasius, P Cognatus, P Delenus, P Alexander, G Urbotius, N Caranaeus en nog andere.

Oor Saravia self het daar so pas ' $n$ nuwe biografiese studie verskyn en wel $W$ Nijenhuis, Adrianus Saravia (1532-1613), Leiden 1980.

39. AD Pont, $a w, b l 60$.

40. AD Pont, $a w$, bl 62.

41. AD Pont, $a w$, bl 78 .

42. AD Pont, $a w$, bl 103.

42. AD Pont, $a w$, bl 137. Interessant is om te let op die besluit van die provinsiale sinode van Gelderland wat in 1580 te Harderwijk byeengekom en besluit het, art 3: Es ist D Wezekio auffgelegt etliche exemplaria von der Bekanndtnus des gelaubens der Niderlendischen Kirchen op des sijnodi oncosten te bestellen, omdat dieselbe van alle kirchendienaeren gelesen und darnach vermoegh des 
eersten artijculs der Dordracen Sijnodi, in loco de doctrina, underschreben werden moege.

Vgl ook J Reitsma en SD van Veen, Acta der Provinciale en Particuliere Synoden, Groningen 1895, Dl 4, bl 10.

44. J Reitsma en J Lindeboom, Geschiedenis van de Hervorming en de Hervormde Kerk der Nederlanden, Groningen 1949, bl $140 \mathrm{vg}$.

45. J Reitsma en J Lindeboom, aw, bl 147-148.

46. So stel die provinsiale sinode van Groningen in 1608: De Nederlandissche Confessie met dem Heidelbergisschen Catechismo ijs avermaals ijn desem synodo niet alleine ingewilliget sondern ock geresolvirt, dat ein iglick classis geholden sall wesen deselve sick tho verschaffen mit rein papir achterijn gebunden, so de itzigen prediger samptlick met hare nakömelinge solen unterteickenen unde solck exemplar ijn gude bewahring holde.

J Reitsma en SD van Veen, aw, Dl 7, bl 142.

47. C Augustijn, aw, bl 60-61.

48. Vgl die Partikuliere Vragen, art 43 by Middelburg 1581. GH Kersten, Kerkelijk Handboekje, Utrecht 1961, bl 143.

49. Beza bou hierdie argument in sy traktaat Response a Jean Hay van 1586.

50. Vgl in hierdie verband ook T Maruyama, The Ecclesiology of Theodor Beza, Genève 1978, p $218 \mathrm{f}$.

51. AD Pont, $a w$, bl 173.

52. J Reitsma en SD van Veen, aw, Dl 5, bl 290.

53. J Reitsma en SD van Veen, aw, Dl 7, bl 218.

54. AD Pont, $a w$, bl 174.

55. C Augustijn, aw, bl 67.

56. Joh Polyander et al, Synopsis Purioris Theologiae, 1625, vert deur Dirk van Dijk, Enschede 1966, Dl 2, bl 290.

57. C Hooijer, Kerkelijke Wetten voor de Hervormden in het Koningrijk der Nederlanden, Zaltbommel 1846, bl 57.

58. Vgl AJ Rasker, De Nederlandse Heroormde Kerk vanaf 1795, Kampen 1974, bl 41-42.

59. A Fiolet, Een Kerk in Onrust om haar Belijdenis, Nijkerk 1953, bl 35.

60. Die formule lui dan: in diep bezef van onze roeping en in vertrouwen op God, dat wij daarin (di die NHK) met ijver en trouw zullen werkzaam zijn om, overeenkomstig de beginselen en het karakter der Hervormde kerk hier te lande, het Evangelie van Jezus Christus te verkondigen, en de belangen van het Godsrijk en in overeenstemming hiermede die van die NHK met opeenvolging van hare verordeningen, naar vermogen te behartigen.

61. JH Scholten, De Leer der Hervormde Kerk, Leiden 1861, Dl 1, bl 116.

62. Aangehaal by AJ Rasker, aw, bl 163.

63. AD Pont, Nicolaas Jacobus van Warmelo 1835-1892, Utrecht 1955, bl 35.

64. C Augustijn, aw, bl $37 \mathrm{vg}$. 